\title{
Role of nitrification inhibitor combined with different nitrogen sources in decreasing injurious components in spinach
}

\begin{abstract}
Vegetables spinach (Spinaciaoleracea L.), represents good sources of vitamins B and $\mathrm{C}$ as well as minerals such as iron, calcium and magnesium, besides the dietary fibers, nitrate and oxalate, which usually affected by both $\mathrm{N}$ rate and form. Therefore, pot experiments were carried out in green house of Agriculture and Veterinary Medicine Experiment Station, Qassim University to find ways to prevent undesirably high nitrate and oxalate contents. However, increasing useful compounds such as vitamins and minerals were also considered. The treatments included two nitrogen sources viz., recommended dose (100\%) of nitrate (NO3-) and ammonia (NH4+), $50 \%$ of each sole or in combination with or without nitrification inhibitor (2-chloro-6-trichloro-methylpyridine-nitrapyrin). Results were noticed that nitrate and oxalate concentrations in spinach leaves were reduced by application $50 \% / 50 \% \mathrm{~N}$ mixture compared with higher rates of each. Noticeable, additional reduction caused in nitrate concentrations, soluble and insoluble oxalates, highest concentrations of vitamins C and B9 as well as minerals contents $(\mathrm{Ca}, \mathrm{K}$ and $\mathrm{Fe})$ in leaves by conjunction mixture with nitrification inhibitor (nitrapyrin). Although highlight results obtained herein, more studies are needed to find out the recommendation can followed by farmers.
\end{abstract}

Volume 2 Issue 6 - 2015

\author{
Alderfasi AA,' Aljuaid AM, ${ }^{2}$ Moftah AE, ${ }^{3}$ Selim \\ $M M^{\prime}$ \\ 'Plant Production Department, King Saud University, Saudi \\ Arabia \\ ${ }^{2}$ Botany Department, Princess NouraBint Abdurrahman \\ University for Girls, Saudi Arabia \\ ${ }^{3}$ College of Agriculture and Veterinary Medicine, Qassim \\ University, Saudi Arabia
}

Correspondence: Alderfasi AA, Production Department, College of Food and Agricultural Sciences, King Saud University, Saudi Arabia, PO Box: 2460 Riyadh I I45I,Tel +966558080 I48, Email aderfasi@ksu.edu.sa

Received: June 20, 2015 | Published: November 25, 2015

Keywords: spinach (spinaciaoleracea 1.), nitrogen sources NO3- NH4, nitrapyrin, nitrate and oxalate contents

\section{Introduction}

Using the suitable culture practices including source of fertilizer application may further increase yield and quality. Nitrogen $(\mathrm{N})$ is known to be the most important macronutrients affecting growth yield and quality of most crops. Excessive application of fertilizers, to enhance growth rates and yield of crops, is a common agricultural practice in developing countries. Due to the increase use of synthetic nitrogen fertilizers and livestock manure in intensive agriculture, vegetables and irrigation water may contain higher concentrations of nitrate now than in the past. ${ }^{1,2}$ The extreme fertilizer application often leads to the accumulation of high levels of nitrates in plant tissues and sometimes builds up in the soil mostly as nitrates. ${ }^{3,4}$

Concerning nitrate and oxalate accumulation, nitrate can indirectly inhibit oxygen transport by blood and caused a medical condition known as methaemoglobinemia which by continues process converted to nitrosamines which causing cancer. Whereas, negative health effects of oxalate accumulation associated with high intake of oxalic acid-occurrence of kidney stone, low plasma levels of iron and calcium, occurrence of calcium deficiency (hypocalcaemia) in humans is highly influenced by excessive nitrate fertilization. ${ }^{5,6}$

Growing leafy vegetables spinach (Spinaciaoleracea L.) supplying nitrogen fertilizer is the major source of nitrate and nitrite, supplying about 72 to $94 \%$ of the total intake. In this concern, earlier studies indicated that the most important factor affecting $\left(\mathrm{NO}_{3}-\mathrm{N}\right)$ contents in plants appears to be the form of applied nitrogen. The ammoniacal fertilizer $\left(\mathrm{NH}_{4}-\mathrm{N}\right)$ may lead to lesser $\mathrm{NO}_{3}-\mathrm{N}$ accumulation in plants, but nitrification by microbial oxidation in soil stimulates the conversion of $\mathrm{NH}_{4}$ to $\mathrm{NO}_{3}{ }^{7}$
Furthermore, the possibility of $\mathrm{NH}_{4}$ toxicity to plants exists when all $\mathrm{N}$ fertilizers are ammoniacal. Previous studies of, ${ }^{1,2,8}$ reported that nitrate to ammonium ratios in plant mineral nutrition can have an influence in the oxalate levels in spinach leaves. Moreover, Palaniswamy et al., 5 found a combination of $\mathrm{NO}_{3}$ and $\mathrm{NH}_{4}$ at a ratio of $0.35 / 0.65$ in hydroponics cultivation of purslane would optimize the nutritional value of leaves (lower oxalic acid and higher omega-3 fatty acid concentrations). In the same concern, Sady et al., ${ }^{9}$ reported that oxalate contents in spinach leaves depended only on the nitrogen form, whereas Beis et al., ${ }^{10}$ reported that one of the factors affecting its leaf oxalate content is position in the stem and ages, they found that younger leaves had lowest oxalate while the older ones had highest oxalates.

Several researchers suggested that nitrification inhibitor such as 2-chloro-6-(trichloromethyl)-pyridine (nitrapyrin), offers a chemical method for maintaining applied $\mathrm{NH}_{4}-\mathrm{N}$ in the soil, and is not harmful to other soil micro flora. The effectiveness of nitrification inhibitor depended upon soil type and the amount of available N..$^{11,12}$

Unfortunately, little information is available on the effect of applied $\mathrm{N}$ fertilizers with different forms sole or in combination with nitrification inhibitor on yield and useful compounds (vitamins and minerals) and minimum accumulation of hazard compounds (nitrate and oxalate) in spinach plant leaves. Therefore, the present study was undertaken to evaluate the interactive effects of different sources and rates of nitrogen fertilizers on plants, Moreover to decrease the negative health effects of nitrate and oxalate accumulation in spinach plant leaves. 


\section{Materials and methods}

In green house (provided with control system) of the Agriculture and Veterinary Medicine Experiment Station, Qassim University, leafy vegetables spinach (Spinaciaoleracea L.) was sown in $35 \mathrm{~cm}$. diameter pots filled with air dried sandy soil $(7 \mathrm{Kg} / \mathrm{pot})$, Chemical and mechanical analyses of the experimental soil are presented in (Table 1) (Table 2)

Table I Chemical analyses of the experimental soil

\begin{tabular}{|c|c|c|c|c|c|c|c|c|c|}
\hline \multirow{2}{*}{ Ph* } & \multirow{2}{*}{$\begin{array}{l}\text { EC } \\
\text { (Ds/M- } \\
\text { I) }\end{array}$} & \multicolumn{3}{|c|}{$\begin{array}{l}\text { Soluble } \\
\text { Cations(Meq/L-I }\end{array}$} & \multicolumn{3}{|c|}{$\begin{array}{l}\text { soluble } \\
\text { anions(Meq/L-I) }\end{array}$} & \multirow{2}{*}{$\mathrm{CaCO} 3$} & \multirow{2}{*}{$\begin{array}{l}\text { O.M } \\
\%\end{array}$} \\
\hline & & $\mathrm{Na}+$ & $\mathrm{Ca}_{2}+$ & $\mathrm{Mg}_{2}+$ & $\mathrm{HCO}_{3}-$ & SO42- & $\mathrm{Cl}-$ & & \\
\hline 8.2 & 2.06 & 11.0 & 4.35 & 2.5 & 2.99 & 11.7 & 7.6 & 4.0 & 0.23 \\
\hline
\end{tabular}

${ }^{*} \mathrm{pH}$ of $\mathrm{H} 2 \mathrm{O}$ (soil:water=2.5: I),**EC: Electric conductivity of the extract soil paste(2:I).

Table 2 Physical properties of the experimental soil

\begin{tabular}{llll}
\hline & $\begin{array}{l}\text { Fractions } \\
(\%)\end{array}$ & Texture \\
\hline Sand & Silt & Clay & Sandy soil \\
95.30 & 3.60 & 1.10 & \\
\hline
\end{tabular}

Before sowing, pots were prepared according to the experimental design of complete randomized design as described by Gomez et al., ${ }^{13}$ in 5 replications. Treatment included 6 fertilization treatments, described as follows: $\left(\mathrm{T}_{1}\right) 100 \%$ Nitrite fertilizer $\mathrm{NO}_{3}-\mathrm{N}$, was applied in the form of potassium nitrate $\left(\mathrm{KNO}_{3}\right)$ contains $(13 \% \mathrm{~N})$ by $(150 \mathrm{Kg} \mathrm{N} /$ ha. $), 100$ $\%$ Ammoniac fertilizer $\left(\mathrm{NH}_{4}-\mathrm{N}\right)$, was applied as ammonium sulphate $\left(\mathrm{NH}_{4}\right) 2 \mathrm{SO} 4$ contains $(21 \% \mathrm{~N})$ by $\left(95 \mathrm{Kg} \mathrm{N} / \mathrm{ha}\right.$.) as $\mathrm{T}_{2} .50 \%$ Nitrite fertilizer $\mathrm{NO}_{3}-\mathrm{N}+50 \%$ ammoniacal fertilizer $\left(\mathrm{NH}_{4}-\mathrm{N}\right)$ was applied as $\mathrm{T}_{3}$ and 50 Nitrite fertilizer $\mathrm{NO}_{3}-\mathrm{N}+$ nitrapyrinapplied as $\mathrm{T}_{4}$ and 50 Ammoniacal fertilizer $\left(\mathrm{NH}_{4}-\mathrm{N}\right)+$ nitrapyrin was applied as $\mathrm{T}_{5}$. Finally, $50 \%$ Nitrite fertilizer $\mathrm{NO}_{3}-\mathrm{N}+50 \%$ ammoniacal fertilizer $\left(\mathrm{NH}_{4}-\mathrm{N}\right)+$ nitrapyrin as $\mathrm{T}_{6}$. Fertilizers were applied in two equal doses; the first one was applied 10 days after sowing, whereas the second was applied 10 days after the application of the first one. Equal dose $(30 \mathrm{~g} / \mathrm{pot})$ of phosphorus fertilizer was applied to all experimented treatments after one week of pots preparation in the form of super phosphate $(15.5 \%$ $\left.\mathrm{P}_{2} \mathrm{O}_{5}\right)$. Nitrapyrin was applied as nitrification inhibitors before sowing to stimulate conversion of $\mathrm{NH}_{4}$ to $\mathrm{NO}_{3}$ and consequently prevent undesirably high nitrate and oxalate content in spinach.

Sowing took place by 15 seeds/pot on $15^{\text {th }}$ January and December, in the first and second season, respectively. Two weeks after sowing, the plants were thinned to 12 plants per pot. During the growth period, 3 representative plant samples after (30, 50 and 70days from sowing) from three replication, each containing four plants were taken for determining, growth parameters expressed as number of leaves, leaf area, fresh, dry weight and leaf water content, (LWC). In the third sample plus the above mention parameters, leave pigments content in the basis of blade area $\left(\mu \mathrm{g} / \mathrm{dm}^{2}\right)$ i.e., chlorophyll $\mathrm{a}, \mathrm{b}$ and carotenoids were determined by the method described by Bruinsma ${ }^{14}$ and their concentration were calculated using the formula used by Porra et al., ${ }^{15}$ For measuring leaf water content (LWC), plant samples were sealed in plastic, placed above ice in cooler and transported to the lab for determination leaf fresh weight, dried at $600 \mathrm{C}$ until constant weight was reached. LWC was calculated according to formula described by Barrs. ${ }^{16}$ Random sample from all plant organs were taken washed with
$0.001 \mathrm{M}$ hydrochloric acid followed by redistilled water to remove contaminations, then dried and ground in stainless steel mill through $0.5 \mathrm{~mm}$. The powdered samples were wet ashed according to the method of Chapman et al. ${ }^{17}$

\section{Chemical analyses were determined as follows:}

Total carbohydrates percentage were determined using spectrophotometer (AAS, Shimazau, AA6200, Kyoto, Japan) and total soluble sugar using soxhelt apparatus by the method described by Dubois et al., ${ }^{18} \mathrm{~N}$ was determined as nitrate using selective specific ion electrode by the method described by Barker et al. ${ }^{19}$ and $\mathrm{P}$ was determined in ashed sample according to the method adopted by King. ${ }^{20}$ While Determination of vitamin $\mathrm{C}$ by calorimetric method according to the method described by Sadasivam et al., ${ }^{21}$ and vitamin B using Diagnostic Automation according to Pffeifer et al. ${ }^{22}$ Determination of oxalate according to the method described by Savage et al., ${ }^{23}$ Results were subjected to statistical analysis of variance described by Gomez et al. ${ }^{13}$ New LSD test as suggested by Waller et al., ${ }^{24}$ was used to means compare.

\section{Results and discussion}

\section{Vegetative growth parameters}

Data manifested in Table 3 showed that highly response of vegetable spinach to nitrogen fertilizers due to quick growth habit and its requirements to adequate nutrients for proper growth metabolic process. However, the influences of nitrogen in plant growth and its role in biochemical synthesis viz., chlorophyll, amino acid, protein, nucleic acid and cytoplasm. ${ }^{25}$ In the same table, noticeable increase in plant height, number of leaves, leaf area, fresh and dry weight and leaf water content (LWC) by application nitrogen fertilizer as form of nitrate, surpassed ammonia form. In the respect of interaction, results obtained herein also indicated that fertilized vegetable spinach with mixture of $50 \% / \% 50 \%$ nitrate/ammonium ratio sole or in the presence of nitrification inhibitor recorded the highest value of most growth parameters. Such practice promoted higher growth in term of plant height, no. of leaves, Leaf area, $\left(\mathrm{cm}^{2}\right)$, fresh weight, $(\mathrm{g})$, dry weight, (g) and leaf water content $(\%)$, due to the favorable nutritional environment and higher uptake. In this concern Zhang et al., ${ }^{26}$ reported that maximum biomass was recorded in vegetable spinach by application nitrogen fertilizer by the ratio of 50/50 of $\mathrm{NO}_{3}-\mathrm{NO}_{4}+$. They added to that obvious decreased was detected as nitrogen ratio $\mathrm{NO}_{3} / \mathrm{NH}_{4}$ ratio of $50 / 50$ decreased from $100 / 0$ to $0 / 100$. In addition, Braymer $^{11}$ found that the effectiveness of nitrification inhibitor depended upon many factors such as soil type and the amount of available $\mathrm{N}$ for plant absorption. Thus salient results obtained herein confirmed that conjunction any form of nitrogen application as well as its interaction with nitrification inhibitor excelled all other tested treatments and registered higher plant vigor. In general, this was true in all growth stages and paralleled with the progressing in plant age. This increase might due to the prevent effect of nitrification inhibitor in conversion ammoniacal $\left(\mathrm{NH}_{4}-\mathrm{N}\right)$ to $\mathrm{NO}_{3}$. The present results in general are in concordance with the finding of Gawish, ${ }^{27} \mathrm{CORF}$ News, ${ }^{28}$ Nosengo $^{3}$ and Xianyong et al. ${ }^{29}$

\section{Leaf pigments content}

Leaf pigments content viz., chlorophyll a, b, and carotenoids are presented in Table 4. Data clearly obvious that, the highest apparent of these components were observed under the treatment $\left(\mathrm{T}_{3}\right)$, which registered the values of $\left(3.54,2.11\right.$ and $\left.0.87 \mu \mathrm{g} / \mathrm{dm}^{2}\right)$ 
for chlorophyll a, b and carotenoids, respectively. This followed by the treatment $\left(\mathrm{T}_{6}\right)$, with $\left(3.44,2.16\right.$, and $\left.0.88 \mu \mathrm{g} / \mathrm{dm}^{2}\right)$. Whereas the application of nitrogen by the both forms as Nitrite $\left(\mathrm{NO}_{3}-\mathrm{N}\right)\left(\mathrm{T}_{1}\right)$ or as ammoniacal $\left(\mathrm{NH}_{4}-\mathrm{N}\right)\left(\mathrm{T}_{2}\right)$, registered nearly the same values for the three parameters without significant differences between them $\left(2.43,1.77\right.$ and $\left.0.82 \mu \mathrm{g} / \mathrm{dm}^{2}\right)$ and $\left(2.65,1.87\right.$ and $\left.0.76 \mu \mathrm{g} / \mathrm{dm}^{2}\right)$ for chlorophyll a, b and carotenoids, respectively. The increment in leaf pigment content might have increase the rate of photosynthesis, proliferation of plant organs, better accumulation and translocation of photosynthates from source to sink. These, thereby increase growth, yield and quality. Our results are in agreement with the earlier reports of Bloom et al., ${ }^{30}$ Palaniswamy et al., ${ }^{6}$ proposed that plants could absorb both nitrogen sources $\mathrm{NO}_{3}-$ and $\mathrm{NH}_{4}+$. Ammonical-N can be directly used by plants in the synthesis of amides and amino acids, whereas $\mathrm{NO}_{3}--\mathrm{N}$ has to be reduced by processes that command up to $25 \%$ of either photosynthetic or mitochondrial electron transport capacity. ${ }^{30}$ However, ammoniacal-N as a sole source of $\mathrm{N}$ acidifies the rhizosphere due to the excretion of $\mathrm{H}^{+}$from plant roots, and can be deleterious to plant growth. ${ }^{31}$ Therefore, a combination of these two forms in an appropriate ratio is generally beneficial in plant growth as concordance with the finding obtained herein in the present investigation and in nutshell the finding reported by Gashaw et al., ${ }^{32}$ Ikeda et al., ${ }^{33}$ Salsac et al. ${ }^{34}$ and Palaniswamy et al. ${ }^{6}$

One of the main objectives of the present study is known to reduce the nitrate and oxalate concentration. However, increase the benefits components such as vitamin C and B9 as well as total soluble sugar and carbohydrate. Results obtained worthy obvious that the highest values of nitrate, soluble and insoluble oxalate in ppm, were shown in plants fertilized with $\mathrm{N}_{-\mathrm{NO}_{3}}\left(5400\right.$ and 4.63) and $\mathrm{N}-\mathrm{NH}_{4}$
(4410 and 3.14) in sole application. The substitution of both form of application by $50 \% / 50 \%$ nitrate/ammonium ratio caused a reduction of nitrate and the oxalate content in spinach leaves. Moreover, conjunction the application of each form and their combinations with nitrification inhibitors (nitrapyrin) caused more reduction in nitrate and he oxalate content and recorded the lowest values of oxalate and nitrate concentration in leaves and the highest values of vitamin $\mathrm{C}$ and $\mathrm{B}$ 9, total soluble sugar and carbohydrate percentage. In this respect Breimer ${ }^{11}$ in pot - and field experiment, reported that partial or complete replacement $\mathrm{NO}_{3}-\mathrm{N}$ by $\mathrm{NH}_{4}-\mathrm{N}$ in general caused the $\mathrm{NO}_{3}$ - content in spinach decreased. However, such a replacement was shown not always result in lower $\mathrm{NO}_{3}$ - contents. Additional factors involved are the use and effectiveness of nitrification inhibitors and the amount of available $\mathrm{N}$ in the soil before sowing.

\section{Macro- nutrients and Fe content}

Treatments under the present investigation were carried out to find ways to prevent high nitrate contents and maintenance vitamins and minerals concentration. Data presented in Table 5 clearly indicated that the highest minerals concentration were achieved by fertilizing spinach plants with $\left(\mathrm{T}_{3}\right)$, followed by the conjunction of the same treatment by nitrification inhibitors (nitrapyrin) $\mathrm{T}_{6}$. Such effect may be attributed to adequate supply of nitrate/ammonium ratio which was enhanced by inoculation with nitrification inhibitor might have resulted in increased mobilization of elements and in turn favorably influenced the plant absorption which finally have increased the growth promoted and higher uptake of nutrients and this might have increased biomass. Similar findings were reported by Breimer ${ }^{11}$ and Zhang et al. ${ }^{26}$

Table 3 Influence of nitrogen forms on some growth parameters of spinach growing in green house (Average of two sowing seasons)

\begin{tabular}{|c|c|c|c|c|c|c|}
\hline Treatment & $\begin{array}{l}\text { Plant height } \\
\text { (Cm) }\end{array}$ & No. of leaves & $\begin{array}{l}\text { Leaf area } \\
(\mathrm{Cm} 2)\end{array}$ & $\begin{array}{l}\text { Fresh weight } \\
\text { (G) }\end{array}$ & $\begin{array}{l}\text { Dry weight } \\
\text { (G) }\end{array}$ & $\begin{array}{l}\text { Water content } \\
\text { (0.A) }\end{array}$ \\
\hline \multicolumn{7}{|c|}{ First sample(30days from sowing) } \\
\hline $\mathrm{T}_{1}$ & 28.6 & 7.2 & 150 & 15.21 & 2.25 & 85.2 \\
\hline $\mathrm{T}_{2}$ & 26.7 & 8.3 & 148 & 12.33 & 1.22 & 90.11 \\
\hline $\mathrm{T}_{3}$ & 30.8 & 9.8 & 195 & 15.85 & 2.76 & 82.27 \\
\hline $\mathrm{T}_{4}^{3}$ & 29.0 & 8.9 & 170 & 15.92 & 2.87 & 81.97 \\
\hline$T_{5}^{4}$ & 29.9 & 6.0 & 125 & 10.68 & 1.05 & 90.17 \\
\hline $\mathrm{T}_{6}$ & 32.3 & 8.3 & 165 & 14.21 & 2.02 & 85.78 \\
\hline LSD at $0.05 \%$ & 2.21 & 1.54 & 29.12 & 2.45 & 0.22 & - \\
\hline \multicolumn{7}{|c|}{ Second sample(50 days from sowing) } \\
\hline $\mathrm{T}_{1}$ & 44.00 & 10.40 & 166.5 & 30.40 & 7.70 & 74.90 \\
\hline $\mathrm{T}_{2}$ & 43.52 & 13.28 & 190.9 & 20.46 & 3.11 & 84.80 \\
\hline $\mathrm{T}_{3}$ & 48.05 & 16.27 & 245.7 & 36.14 & 6.22 & 82.79 \\
\hline $\mathrm{T}_{4}$ & 46.66 & 15.70 & 214.7 & 35.64 & 5.22 & 85.35 \\
\hline $\mathrm{T}_{5}$ & 43.65 & 17.15 & 190.0 & 26.02 & 4.00 & 84.63 \\
\hline $\mathrm{T}_{6}$ & 52.97 & $|4.6|$ & 224.4 & 31.55 & 5.19 & 83.56 \\
\hline LSD at $0.05 \%$ & 2.21 & 1.32 & 27.42 & 2.15 & 0.12 & - \\
\hline \multicolumn{7}{|c|}{ Third sample(70 days from sowing) } \\
\hline $\mathrm{T}_{1}$ & 53.73 & 11.70 & 469.5 & 54.20 & 12.9 & 76.3 \\
\hline$T_{2}$ & 53.53 & 18.19 & 431.5 & 45.02 & 7.50 & 83.34 \\
\hline $\mathrm{T}_{3}$ & 59.10 & 22.78 & 540.5 & 49.51 & 11.94 & 75.88 \\
\hline $\mathrm{T}_{4}$ & 57.43 & 21.83 & 433.7 & 45.76 & 8.96 & 80.42 \\
\hline$T_{5}$ & 51.79 & 21.95 & 418.0 & 33.80 & 3.68 & 89.11 \\
\hline $\mathrm{T}_{6}$ & 61.98 & 21.62 & 479.2 & 44.80 & 10.69 & 76.14 \\
\hline LSD at $0.05 \%$ & 4.11 & 4.12 & 64.32 & 3.11 & 1.21 & - \\
\hline
\end{tabular}


Table 4 Leaf pigment contents and nitrate, oxalate as well as vitamins concentration spinach leaves as affected by source of nitrogen application (Average of two growing seasons)

\begin{tabular}{|c|c|c|c|c|c|c|c|c|c|c|}
\hline \multirow[b]{2}{*}{ Treatment } & \multicolumn{4}{|c|}{ Leaf pigment contents, ( $\mu$ g/Dm2) } & \multicolumn{3}{|c|}{ Chemical composition of plants } & \multirow{2}{*}{$\begin{array}{l}\text { Tissue } \\
\text { Carbohydrate } \\
\text { (\%) }\end{array}$} & \multicolumn{2}{|c|}{ Leaf vitamin Content } \\
\hline & Chl.(a) & Chl.(b) & Carotenoid & Nitrate(ppm) & $\begin{array}{l}\text { Soluble } \\
\text { Oxalate } \\
\text { (ppm) }\end{array}$ & $\begin{array}{l}\text { Insoluble } \\
\text { Oxalate } \\
\text { (ppm) }\end{array}$ & $\begin{array}{l}\text { *TSS (mgl } \\
\text { gdwt) }\end{array}$ & & $\begin{array}{l}\text { Vitamin C } \\
\text { (Ascorbic } \\
\text { acid) } \\
(\mathrm{mg} / \mathrm{l00g})\end{array}$ & $\begin{array}{l}\text { Vitamin B9 } \\
\text { (Folic acid) } \\
(\mu \mathrm{g} / 100 \mathrm{~g})\end{array}$ \\
\hline $\mathrm{T}_{\mathrm{I}}$ & 2.43 & 1.77 & 0.82 & 5400 & 4.63 & 8.42 & 3.2 & 13.3 & 42.7 & 85 \\
\hline $\mathrm{T}_{2}$ & 2.65 & 1.87 & 0.76 & 4410 & 3.14 & 6.21 & 3.9 & 14.5 & 52.9 & 90 \\
\hline $\mathrm{T}_{3}$ & 3.54 & 2.11 & 0.87 & 3000 & 1.63 & 5.83 & 5.5 & 19 & 60.6 & 112 \\
\hline $\mathrm{T}_{4}$ & 3.77 & 2.22 & 0.83 & 4100 & 1.44 & 5.77 & 5.32 & 15.64 & 62.51 & 96 \\
\hline $\mathrm{T}_{5}$ & 2.43 & 1.66 & 0.74 & 4200 & 1.82 & 5.62 & 4.2 & 15.5 & 55.7 & 95 \\
\hline $\mathrm{T}_{6}$ & 3.44 & 2.16 & 0.88 & 2170 & 1.25 & 4.84 & 5.8 & 20 & 62.6 & 115 \\
\hline LSD at $0.05 \%$ & 60.34 & 0.52 & 0.26 & 825 & 0.12 & 1.02 & 1.21 & --------- & 9.25 & 35.2 \\
\hline
\end{tabular}

Table 5 Mean of macro and micronutrient concentration in spinach leaves as affected by different fertilizer sources on (Average of two growing seasons)

\begin{tabular}{llllll}
\hline \multirow{2}{*}{ Treatment } & \multicolumn{5}{c}{ Percentage of macro-nutrients content, and Fe in(ppm) } \\
\cline { 2 - 6 } & $\mathbf{N}$ & $\mathbf{P}$ & $\mathbf{K}$ & $\mathbf{C a}$ & $\mathbf{F e}$ \\
\hline $\mathrm{T}_{1}$ & 3.50 & 0.43 & 6.80 & 1.53 & 54.12 \\
$\mathrm{~T}_{2}$ & 3.90 & 0.45 & $5.1 \mathrm{I}$ & $\mathrm{I} .2 \mathrm{I}$ & $55.1 \mathrm{I}$ \\
$\mathrm{T}_{3}$ & 4.88 & 0.72 & 5.85 & 1.65 & 77.70 \\
$\mathrm{~T}_{4}$ & 3.98 & 0.68 & 5.47 & 1.54 & 68.92 \\
$\mathrm{~T}_{5}$ & 4.10 & 0.45 & $5.2 \mathrm{I}$ & $1.3 \mathrm{I}$ & 66.60 \\
$\mathrm{~T}_{6}$ & 4.95 & 0.73 & 5.95 & 1.75 & 87.40 \\
$\mathrm{LSD}$ at $0.05 \%$ & 0.22 & 0.65 & 0.88 & 0.34 & 2.92 \\
\hline
\end{tabular}

\section{Conclusion}

Form of nitrogen application appeared to be most important factor affecting on oxalate and nitrate - content in spinach. Both forms of $\mathrm{N}$ application under the present study in mixtures by the ratio of $50 \% / 50 \%$ nitrate/ammonium excelled all other tested treatments. The results further demonstrated that conjunction either both forms of $\mathrm{N}$ application in sole or their mixture with nitrification inhibitors (nitrapyrin) reduce undesirably high nitrate and oxalate contents of spinach.

\section{Acknowledgements}

None.

\section{Conflict of interest}

The author declares no conflict of interest.

\section{References}

1. Santamaria P. Nitrate in vegetables:Toxicity content, Intake and EC Regulation. J Sci Food Agric. 2005;86(1):10-17.
2. Uwah EI, Ndahi NP, Abdul rahman FI, et al. Measurement of nitrate and nitrite contents in soil and some leguminous vegetables cultivated in maiduguri, Nigeria. World Journal of Agricultural Sciences. 2009;5:881887.

3. Nosengo N. Fertilized to Death. Nature. 2003;425:894-895.

4. Goh KM, Vityakon P. Effects of fertilizers on vegetable production. 2Effects of nitrogen fertilizer on nitrogen content and nitrate accumulation of spinach and beet root. NZ J Agric Res. 1986;29:485-494.

5. Palaniswamy UR, Mc Avoy RJ, Bible BP. Omega-3-fatty acid concentration in Portulaca oleracea L. is altered by nitrogen source in hydroponic solution. J Am Soc Hort Sci. 2000;125(2):190-194

6. Palaniswamy UR, Bible BP, Mc Avoy RJ. Effect of nitrate:ammonium nitrogen ration on oxalate levels of purslane. In: Janick J, et al. editors. Trends in New Crops and New Uses. Alexandria, USA: ASHS Press; $2002 ; 4: 453-455$.

7. Goh KM, Vityakon P. Ionic composition and oxalate accumulation of spinach and beet root as affected by rates and forms of nitrogenous fertilizers applied. Thi J Agric Sci. 1988;21:189-216.

8. Ahmed AK, Johnson KA. The effect of the ammonium nitrogen ratio, total nitrogen, salinity $(\mathrm{NaCl})$ and calcium on the oxalate levels of Tetragoniate tragonioides Pallas. Kunz J Hort Sci Biotechnol. 2000;75:533-538. 
9. Sady W, Kowaska I. Effect of nitrogen for or solution $\mathrm{pH}$ on cadmium content and quality of spinach. ISHS Acta Horti culture 7000: Internationa Symposium towards Ecologically Sound Fertilization Strategies for Field Vegetable Production; 2007.

10. Beis GH Siomos, AS, Dogras, CC. Spinach composition as affected by leaf age and plant part. ISHS Acta Horticulurae 579: II Balkan Symposium on Vegetables and Potatoes; 2002.

11. Breimer T. Environmental factors and cultural measures affecting the nitrate content in spinach. Nutrient Cycling in Agroecosystem. 1982;3(3):191-292.

12. Mills HA, Barker AV, Naynard DN. Effects of nitrapyrine on nitrate accumulation in spinach. J Amer Hort Sci. 1976;101:202-204.

13. Gomez K, Gomez A. Statistical Procedure for Agricultural Research. 2nd ed. Hand book. New York, USA: John Wiley \& Sons; 1984. p. 1-690.

14. Bruinsma J. The quantitative analysis of chlorophylls a and $\mathrm{b}$ in plan extracts. Photochem Photobiol. 1963;2(2):241-249.

15. Porra J, Thompson WA, Kriedermann PE. Determination of accurate extinction coefficients and simultaneous equations for assaying chlorophylls $\mathrm{a}$ and $\mathrm{b}$ extracted with four different solvents:verification of the concentration of chlorophyll standards by atomic absorption spectroscopy. Biochimicaet Biophysica Acta. 1989;975:384-394.

16. Barrs HD. Determination of water deficit in plant tissues. In:TT Kozlowski editor. Water deficit and plantgrowth. New York, USA: Academic Press; 1968. p. 235-368.

17. Chapman HD, Pratt PP. Methods of analysis for solids, plant and water University of California, Division of Agric Sci. 1961;5:209-211.

18. Dubois M, Gilles KA, Hamilton J, et al. Colorimetric method for determination of sugar and related substances. Anal Chem. 1956;28(3):350 356.

19. Barker AV, Peck NH, MacDonal GE. Nitrate accumulation in vegetables 1-Spinach grown in upland soils. Agron J. 1971;63:126-129.

20. King EJ. Micro-Analysis in Medical Biochemistry. 2nd ed. Churchill. London; 1951.

21. Sadasivam S, Manickam A. Vitamins. Biochemical Methods for Agricultural Sciences. New Delhi, India: Wiley East Pub; 1992;12:173180.
22. Pffeifer CM, Rogers LM, Gregory JF. Determination of folate in cereal grain food products using tri-enzyme extraction. JAgric Food Chem. 1997;45(2):407-413.

23. Savage GP, Vanhanen L, Mason SL, et al. Effect of cooking on the soluble and insoluble oxalate content of some New Zealand foods. J Food Comp Anal. 2000;13:200-201.

24. Waller RA, Duncan DB. A boyo rule for the symmetric multiple comparison problem. Amer Stat Assoc Jour. 1969. p. 1485-1508

25. Taiz L, Zeiger E. Mineral nutrition. Plant Physiology. 3rd ed. Sinauer Assoc Inc., Massachusetts, USA: Publisher; 2002;5:67-86.

26. Zhang Y, Lin X, Zhang Y, et al. Effect of nitrogen levels and nitrate/ ammonium ratio on oxalate concentration of different plant organs. Journal of plant nutrition. 2005;28(11):2011-2025.

27. Gawish R. Trials to reduce nitrate and oxalate contents in some leaf vegetables. Zagazig J Agric Res. 1997;24:83-94.

28. CORF News. Nitrogen nutrition:Effect of Ammonium vs. nitrate on plant growth and development. Calif Ornam Res Fedr News. 2000;4:1-3.

29. Xianyong L, Yongsong Z. Optimizing the nitrogen / potassium balance for high quality spinach. Better Crop. 2005;89:22-24.

30. Blom Zandstra M. Nitrate accumulation in vegetables and its relationship to quality. Ann Appl Biol. 1989;155:553-561.

31. Weir BS, RW Allard, AL Kahler. Analysis of complex allozyme polymorphisms in a barley population. Genetics. 1972;72:505-523.

32. Gashaw L, Mugwira LM. Ammonium-N and nitrate-N effects on the growth and mineral compositions of Triticale, wheat, and rye. Agron J. 1981;73:47-51.

33. Ikeda H, T Osawa. Effects of ratios of $\mathrm{NO}$ to $\mathrm{NH}$ and concentrations of each $\mathrm{N}$ source in the nutrient solution on growth and leaf $\mathrm{N}$ constituents of vegetable crops and solution pH. J Japan Soc Hort Sci. 1983;52:363-380.

34. Salsac L, Chaillou S, Morot Gaudry JF, et al. Nitrate and ammonium nutrition in plants. Plant Physiol Biochem. 1987;25:805-812. 